\title{
Strategi Pengembangan Usaha Kerajinan Bambu di Wilayah Kampung Pajeleran Sukahati Kecamatan Cibinong Kabupaten Bogor
}

\author{
Budi Setiawan \\ Prodi Manajemen STIE Cibinong, Bogor
}

\begin{abstract}
Bamboo handicraft business at rural areas, of Pajeleran Sukahati, Cibinong of Bogor district, Indonesia is estimated to have lasted since the 1960s carried from generation to generation. Some types of bamboo handicraft products routinely produced are variety of furniture products like tables and chairs. This study aims to know the description of the existence of craftsmen, the strengths and weaknesses as well as strategies that can be owned implemented for business development. Based on survey results revealed that the total value of IFE matrix owned by the craftsman is 3.00 and the total value of EFE matrix is 3.05. Further analysis of these results is phase matching, which produces information that the presence of artisans into the first cells that means grows and develops. There are three alternative strategies that can be applied by the craftsmen in developing their business are: 1). Market penetration; 2). Development or expansion of the market; and 3). Products development. Based on QSPM result, products development has a highest score of Total Attractive Score (TAS), so it's has been chosen as the most recommended strategy.
\end{abstract}

Keywords: Bamboo Handicraft, Small Medium Enterprises, Business Development strategy, SWOT Analysis.

\section{Pendahuluan}

Kondisi perekonomian bangsa Indonesia pernah terguncang dahsyat dan terpuruk pada era 1998-an. Krisis ekonomi yang terjadi, berdampak pada terganggunya stabilitas bangsa secara mikro maupun makro. Sampai dengan saat ini Pemerintah dan seluruh elemen bangsa senantiasa berusaha dengan keras agar dapat menjadi bangsa dengan sistem perekonomian yang lebih tangguh dan tak mudah terpuruk sebagaimana pernah terjadi pada era 1998-an tersebut.

Satu hal yang menarik bagi penulis adalah hasil pengamatan dampak krisis ekonomi tahun 1998 terhadap 225.000 Usaha Kecil Menengah (UKM) di Indonesia sebagaimana dipaparkan oleh Anuraga dan Sudantoko (2002), sebagaimana disajikan pada Gambar 1. Berdasarkan Gambar 1, diketahui bahwa keberadaan UKM memiliki kemampuan bertahan usaha yang relatif lebih kuat terhadap situasi perekonomian bangsa yang sedang terpuruk $(64,10 \%)$, dan hanya sebesar 4\% dari UKM yang dijadikan sampel penelitian mengalami kebangkrutan. Keberadaan UKM mampu menjadi solusi efektif dalam menangani permasalahan 


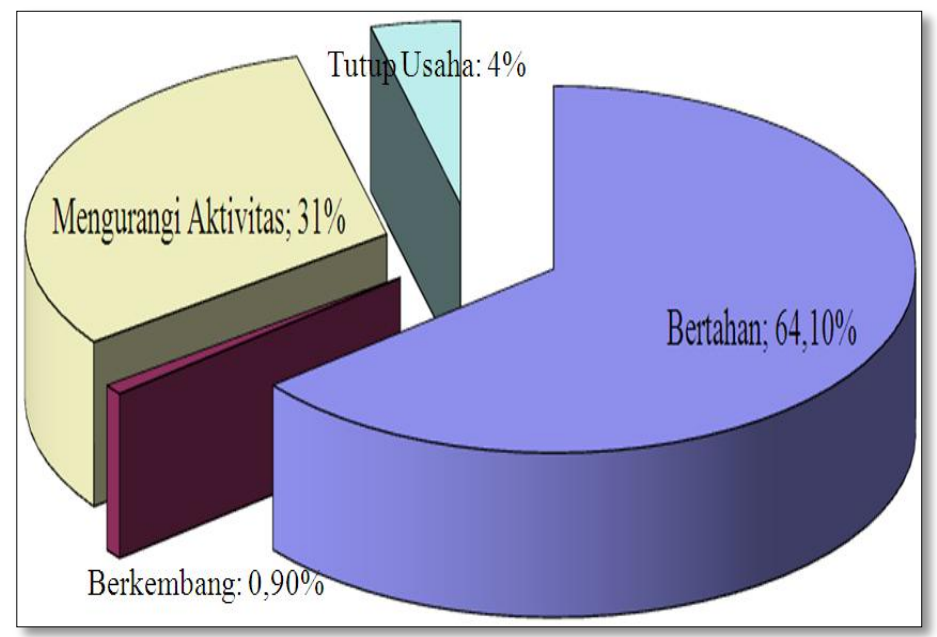

Gambar 1. Hasil Pengamatan Dampak Krisis Ekonomi Tahun 1998 Terhadap 225.000 UKM Seluruh Indonesia Yang Teridentifikasi

pengangguran, dikarenakan keberadaannya yang stabil dan sifat usahanya yang padat karya.

Salah satu keberadaan UKM yang terdapat di wilayah Kelurahan Sukahati dan memiliki potensi untuk dikembangkan adalah usaha kerajinan bambu. Usaha ini diperkirakan telah ada sejak tahun 1960-an, dijalankan sebagian besar oleh warga asli (pribumi) Sukahati, secara turun temurun dari generasi ke generasi. Ketersediaan pengrajin bambu di wilayah Kelurahan Sukahati tersebar di berbagai kampung, namun berdasarkan hasil observasi diketahui bahwa paling dominan berada di wilayah Kampung Pajeleran. Ketersediaan tenaga kerja berkisar antara 1 sampai dengan 3 orang. Bentuk kerajinan yang secara general dihasilkan adalah berbagai perlengkapan furniture rumah tangga, yang memiliki desain dan nilai seni relatif tinggi.

Bambu merupakan produk hasil hutan nonkayu yang telah dikenal dan sangat dekat dengan kehidupan masyarakat umum karena pertumbuhannya ada di sekeliling kehidupan masyarakat. Bambu termasuk dalam tanaman Bamboidae anggota subfamilia rumput, memiliki keanekaragam jenis bambu di dunia sekitar 1250 - 1500 jenis sedangkan Indonesia memiliki hanya $10 \%$ sekitar 154 jenis bambu (Wijaya et al. 2004).

Dalam kehidupan masyarakat pedesaan di Indonesia, bambu memiliki peranan yang sangat penting. Bahan bambu memiliki sifat-sifat yang baik untuk dimanfaatkan, antara lain batangnya kuat, ulet, lurus, rata, keras, mudah dibelah, mudah dibentuk dan ringan. Selain itu harga perolehan bambu juga relatif murah dibandingkan dengan bahan bangunan lain karena banyak ditemukan di sekitar pemukiman pedesaan.

Penjualan bambu dalam bentuk barang kerajinan memiliki nilai ekonomis yang lebih tinggi dibandingkan cara penjualan bambu secara langsung berupa batangan bambu. Hal ini dikarenakan bambu yang dibuat dalam berbagai bentuk barang kerajinan seperti bangku, meja, tirai dan lain sebagainya, dapat dijual dengan nilai margin yang jauh lebih besar dibandingkan tanpa dibentuk dalam barang kerajinan. 
Tujuan dari penelitian ini adalah untuk mengetahui:

a. Gambaran keadaan usaha kerajinan bambu di Kampung Pajeleran Sukahati

b. Kekuatan dan kelemahan yang terdapat pada usaha kerajinan tersebut

c. Strategi yang dapat diimplementasikan dalam mengembangkan keberadaan usaha kerajinan tersebut

\section{Metode Penelitian}

Metode penelitian yang digunakan penulis adalah metode penelitian deskriptif analisis, yang merupakan suatu metode penelitian untuk memperoleh gambaran mengenai situasi dan keadaan dengan cara memaparkan data yang diperoleh sebagaimana adanya yang kemudian melalui berbagai analisis dibuat beberapa kesimpulan.

\section{II.1. Kerangka Pemikiran}

Penulis melakukan observasi kepada para pengrajin yang telah dijadikan sampel penelitian, untuk kemudian dilakukan kegiatan wawancara. Kegiatan observasi dan wawancara kepada para pengrajin bambu ini dilakukan penulis agar dapat dilakukan identifikasi SWOT, yakni kekuatan dan kelemahan yang masuk dalam matriks Internal Factors Evaluation (IFE), dan peluang serta tantangan yang masuk dalam matriks External Factors Evaluation (EFE). Hasil skor yang diperoleh dari matriks IFE dan EFE ini selanjutnya setelah dilakukan tahap pencocokan, maka akan dapat memberikan gambaran keberadaan usaha dan menetapkan beberapa alternatif strategi yang dapat diimplementasikan dalam mengembangkan usaha kerajinan bambu di wilayah Kampung Pajeleran. Penulis menetapkan keputusan pemilihan strategi yang paling baik dengan menggunakan teknik Quantitative Strategies Planning Matrix (QSPM).

Umar (2001:245) mengatakan bahwa QSPM adalah alat yang direkomendasikan bagi para ahli strategi untuk melakukan evaluasi pilihan strategi alternatif secara objektif, berdasarkan key succes factors internal-eksternal yang telah diidentifikasikan sebelumnya. Seperti alat analisis untuk memformulasikan strategi lainnya, QSPM juga memerlukan intuitive judgment yang baik.

Untuk dapat mengetahui keragaman dari pengrajin, maka penulis melakukan observasi pada UKM yang dipilih secara sengaja (purposive sampling) sebanyak 20 pengrajin dari populasi sebanyak 53 pengrajin yang berada di wilayah Sukahati (Sumber: Laporan Tahunan Kelurahan Sukahati 2009). Bobot dan rating ditetapkan penulis berdasarkan hasil wawancara dan observasi dengan pengrajin. Sedangkan dalam hal penerapan QSPM penulis hanya menetapkan tiga orang pengrajin, yang dapat menjadi representatif seluruh pengrajin. Mengingat keterbatasan latar belakang pendidikan formal dari pengrajin, maka dalam penetapan skor dilakukan setelah melalui proses wawancara yang mendalam dengan responden. Ketiga responden yang penulis asumsikan dapat menjadi representatif informasi yang dibutuhkan dari seluruh pengrajjin, adalah sebagai berikut:

a. Pengepul bambu

b. Pengrajin senior atau yang dianggap sesepuh oleh pengrajin lainnya 
c. Pengrajin dengan kapasitas produksi, secara relatif di atas kapasitas produksi pengrajin lain pada umumnya.

\section{II.2. Teknik Analisis Data}

Khusus dalam hal analisis data untuk matriks IFE dan EFE, maka penulis mengacu kepada pemaparan Hunger \& Wheelen (2003), yakni dilakukan dengan urutan proses analisis sebagai berikut:

a. Analisis IFE:

1. Melakukan identifikasi dan menuliskannya pada kolom 1, tentang kekuatan dan kelemahan dari pengrajin bambu.

2. Menetapkan bobot dari masing-masing faktor pada kolom 2, mulai dari 1.0 (paling penting) sampai 0.0 (tidak penting). Total semua bobot harus berjumlah 1.0. Semakin besar bobotnya, maka semakin besar prioritas faktor tersebut bagi pengrajin bambu.

3. Menetapkan tingkat peringkat dalam kolom 3 untuk setiap faktor dengan angka 4 (baik), 3 (rata-rata), 2 (di bawah rata-rata), 1 (buruk).

4. Setiap peringkat adalah penelitian analisis tentang seberapa baik pengrajin merespon dan mengatasi setiap faktor internal.

5. Kalikan masing-masing bobot dengan peringkatnya untuk memperoleh skor terbobot yang akan ditulis pada kolom ke-4.

6. Tambahkan seluruh skor terbobot sehingga diperoleh total skor terbobot kemudian hasilnya pada baris terakhir kolom ke-3. total skor terbobot memiliki interval dari angka 4.0 (baik sekali) sampai 1.0 (buruk).

b. Analisis EFE:

1. Melakukan identifikasi dan menuliskannya pada kolom 1, tentang peluang dan ancaman.

2. Menetapkan bobot dari masing-masing faktor pada kolom 2, mulai dari 1.0 (paling penting) sampai 0.0 (tidak penting). Total semua bobot harus berjumlah 1.0. semakin besar bobotnya, semakin besar prioritas faktor tersebut bagi pengrajin.

3. Menetapkan tingkat peringkat dalam kolom 3 untuk setiap faktor dengan angka 4 (baik), 3 (rata-rata), 2 (di bawah rata-rata), 1 (buruk). Setiap peringkat adalah penelitian analisis tentang seberapa baik pengrajin mampu merespon dan mengatasi setiap faktor eksternal.

4. Kalikan masing-masing bobot dengan peringkatnya untuk memperoleh skor terbobot yang akan ditulis pada kolom ke-4.

5. Tambahkan seluruh skor terbobot sehingga diperoleh total skor terbobot kemudian hasilnya pada baris terakhir kolom ke-3. total skor terbobot memiliki interval dari angka 4.0 (baik sekali) sampai 1.0 (buruk).

Langkah pengembangan QSPM sebagaimana diolah dari pemaparan Umar (2001) adalah sebagai berikut:

1. Membuat daftar peluang, ancaman, kekuatan, dan kelemahan pengrajin di kolom sebelah kiri QSPM. Informasi ini diambil dari EFE Matrix dan IFE Matrix.

2. Beri Weight pada masing-masing external dan internal key succes factors. Weight ini sama dengan yang ada di EFE Matrix dan IFE Matrix. 
3. Catat strategi-strategi alternatif di bagian atas baris QSPM.

4. Tetapkan Attractiveness Score (AS), yaitu nilai yang menunjukkan kemenarikan relatif untuk masing-masing strategi yang terpilih. Batasan nilai AS adalah $1=$ tidak menarik, 2 = agak menarik, 3 = secara logis menarik, 4 = sangat menarik.

5. Hitung Total Attractive Score (TAS), yang dapat menunjukkan relative attractiveness dari masing-masing alternatif strategi.

6. Hitung Sum Total Attractiveness Score dengan menjumlahkan semua TAS pada masing-masing kolom QSPM. Nilai TAS tertinggi dari alternatif strategi menjadi pilihan utama yang paling direkomendasikan.

\section{Hasil Penelitian}

\section{III.1. Gambaran Umum Usaha Kerajinan Bambu di Kampung Pajeleran}

Pengrajin Bambu Kampung Pajeleran pada umumnya merupakan warga pribumi Kelurahan Sukahati Kecamatan Cibinong Bogor. Pada kampung ini mudah ditemukan para pengrajin bambu, mulai dari yang dikerjakan sendiri sampai dengan yang dibantu dengan para pegawai (tenaga kerja) yang berjumlah 1 sampai 3 orang. Dalam hal ini pemilik usaha selain bertindak sebagai manager juga merangkap sebagai tenaga kerja langsung. Latar belakang pendidikan formal pengrajin pada umumnya adalah pendidikan setingkat SMP atau Madrasah Tsanawiyah ke bawah. Walaupun demikian, kemampuan dan keterampilan mereka dalam menciptakan produk kerajinan bambu tidak perlu diragukan lagi.

Ketersediaan tenaga kerja pada umumnya masih terdapat hubungan keluarga. Hal ini dapat membawa keuntungan dan juga kerugian. Keuntungannya adalah upah yang diberikan sangat negotiable dan cenderung lebih efisien. Selain itu hal ini juga dapat memberdayakan anggota keluarga yang masih belum memiliki pekerjaan tetap. Sedangkan kerugiannya adalah agak sulit bagi pengrajin untuk bersikap tegas apabila ada beberapa perbedaan pandangan.

Produk furniture bambu yang dihasilkan oleh para pengrajin cukup bervariasi, namun beberapa jenis kerajinan yang rutin dan secara teratur dibuat oleh pengrjin adalah seperti:

1. Kursi (kursi malas/rosbang, kursi tamu biasa, kursi tamu anyaman rotan, balai/dipan besar).

2. Meja (meja tamu biasa, meja tamu anyaman rotan).

3. Kerai (penutup silau/panas matahari)

4. Tangga

Bahan baku yang digunakan adalah bambu dengan jenis bambu hitam, tali (benang sepatu), rotan, paku dan cat pernis. Sedangkan peralatan yang digunakan adalah sangat sederhana (tradisional) seperti gergaji, palu, golok dan pisau. Bahan baku utama yakni bambu jenis bambu hitam diperoleh dengan cara membeli pada penjual bambu (pengepul) yang mendatangkan bambu secara khusus dari berbagai wilayah seperti Sukabumi, Jampang Surade, Parung dan lain sebagainya.

Jenis kerajinan bambu yang dihasilkan berdasarkan karakteristik desain produknya terdiri dari dua kelompok. Pertama adalah jenis kerajinan bambu yang bersifat 
original, artinya produk kerajinan yang dihasilkan sepenuhnya menggunakan bahan baku bambu, bentuk atau desain yang kaku (standard), proses pengerjaan yang lebih cepat dan lebih sederhana. Sedangkan jenis kerajinan bambu yang telah mengalami pengembangan adalah produk kerajinan yang dihasilkan telah dikombinasikan dengan bahan baku lain seperti rotan, bentuk atau desain yang unik, lebih menarik, namun proses pengerjaannya membutuhkan waktu yang lebih lama dan lebih rumit.

Dalam aspek permodalan diketahui bahwa pengrajin pada umumnya menggunakan modal sendiri dan belum memanfaatkan pinjaman perkuatan modal usaha dari Bank. Hal ini terjadi dikarenakan terjalinnya kepercayaan yang cukup baik antara pengrajin dengan penjual bambu (pengepul) dan antara pengrajin dengan tenaga pemasarnya.

Teknologi yang digunakan oleh pengrajin sepenuhnya menggunakan teknologi sederhana (tradisional), yakni seperti golok, gergaji, dan pisau. Produk kerajinan bambu yang dihasilkan merupakan hasil keterampilan tangan para pengrajin dalam menyusun, menganyam dan mengikat batangan-batangan bambu yang telah dipotong sesuai ukuran dan model.

Penentuan harga jual produk dilakukan dengan memperhitungkan harga bahan baku yang digunakan, gaji karyawan, lama waktu yang dibutuhkan dan tingkat kesulitan dalam pengerjaannya serta berbagai biaya overhead lainnya. Berlaku pula harga pasar, sehingga produk yang dijual memiliki standar harga yang disepakati bersama.

Usaha ini termasuk usaha kreatif, maka komponen biaya bahan baku tidak menjadi patokan mutlak dalam penentuan harga jual, namun lebih kepada lama waktu yang dibutuhkan dalam membuat produk, tingkat kesulitan dan desain dari produk.

Bahan baku utama (bambu hitam) diperoleh dengan cara membeli pada pedagang bambu (pengepul). Harga jual per April 2010 yang ditetapkan oleh pengepul adalah Rp 8.000,- (delapan ribu rupiah) per batang. Dalam hal ini pengepul bambu mengambil margin sebesar Rp 500,- (lima ratus rupiah) untuk tiap batang bambu yang dijualnya. Sebagai gambaran dalam penetapan harga jual produk, berdasarkan pada hasil wawancara maka penulis memaparkannya dalam beberapa tabel berikut ini.

Tabel 1. Kisaran Biaya Produksi dan Penetapan Harga Jual Produk Set Meja Kursi Tipe Biasa

\begin{tabular}{|c|c|c|c|c|}
\hline No & Uraian & Satuan & $\begin{array}{l}\text { Biaya } \\
\text { Satuan }\end{array}$ & Jumlah \\
\hline 1 & $\begin{array}{l}\text { Bambu } \\
\text { hitam }\end{array}$ & 6 batang & $8.000,-$ & $48.000,-$ \\
\hline 2 & Tali Ikat & 1 gulung & $5.000,-$ & $5.000,-$ \\
\hline 3 & Cat Pernis & $\begin{array}{l}1 \text { kaleng } 1 / 2 \\
\mathrm{~kg}\end{array}$ & $\begin{array}{r}20.000, \\
-\end{array}$ & 20.000,- \\
\hline 4 & Ampelas & $1 / 2$ meter & 12.000, & $6.000,-$ \\
\hline 5 & Tenaga Kerja & 1 ls & $\begin{array}{r}\text { 16.000, } \\
-\end{array}$ & 16.000,- \\
\hline \multicolumn{4}{|c|}{ Jumlah } & 95.000,- \\
\hline \multicolumn{4}{|c|}{ Harga Jual ke Pemasar/ Pedagang (kios) } & 130.000,- \\
\hline \multicolumn{4}{|c|}{ Margin Keuntungan } & $36,84 \%$ \\
\hline \multicolumn{4}{|c|}{ Lama waktu pengerjaan } & 1,5 hari \\
\hline
\end{tabular}

Sumber: Observasi dan Wawancara 2010 
Tabel 2. Kisaran Biaya Produksi dan Penetapan Harga Jual Produk Set Meja Kursi Tipe Betawi

\begin{tabular}{|c|c|c|c|c|}
\hline No & Uraian & Satuan & $\begin{array}{c}\text { Biaya } \\
\text { Satuan }\end{array}$ & Jumlah \\
\hline 1 & Bambu hitam & 11 batang & $8.000,-$ & $88.000,-$ \\
\hline 2 & Tali Ikat & 1 gulung & $5.000,-$ & 5.000,- \\
\hline 3 & Rotan Ikat & $2 \mathrm{~kg}$ & $25.000,-$ & 50.000,- \\
\hline 4 & Cat Pernis & $\begin{array}{l}1 \text { kaleng } 1 / 2 \\
\mathrm{~kg}\end{array}$ & 20.000,- & 20.000,- \\
\hline 5 & Ampelas & 1 meter & 10.000,- & 10.000,- \\
\hline 6 & Tenaga Kerja & $1 \mathrm{ls}$ & $35.000,-$ & $35.000,-$ \\
\hline \multicolumn{4}{|c|}{ Jumlah } & 208.000,- \\
\hline \multicolumn{4}{|c|}{ Harga Jual ke Pemasar/ Pedagang (kios) } & 450.000,- \\
\hline \multicolumn{4}{|c|}{ Margin Keuntungan } & $116,4 \%$ \\
\hline \multicolumn{4}{|c|}{ Lama waktu pengerjaan } & 7 hari \\
\hline
\end{tabular}

Bambu yang dijual oleh pengepul pada umumnya memiliki bentuk atau ukuran yang sama, dan sebagian kecilnya memiliki ukuran yang sedikit lebih besar. Oleh pengrajin bambu tersebut dilihat atau diperiksa terlebih dahulu kekeringannya. Apabila masih terasa basah/lembab, maka bambu tersebut akan terlebih dahulu dijemur selama minimal 1 hari. Hal ini dilakukan untuk mencegah bambu terkena bubuk yang dapat membuat bambu menjadi mudah keropos.

Selain itu, untuk barang kerajinan bambu yang telah dimodifikasi (tipe Betawi) maka pengrajin juga memerlukan rotan sebagai bahan untuk mengikat di antara tiap siku dari produk kerajinan bambu sebagai nilai seni yang tinggi dan menciptakan keunikan tersendiri. Bahan baku pendukung yang dibutuhkan oleh pengrajin bambu dalam membuat produk kerajinannya adalah seperti tali ikat dan cat pernis.

Batangan bambu yang telah tersedia selanjutnya dipotong sesuai dengan panjang yang dibutuhkan untuk tiap jenis produk yang akan dihasilkan. Bambu yang telah dipotong tersebut selanjutnya disusun dan disambungkan batang demi batang membentuk kerangka dari produk yang akan dihasilkan. Proses ini hanya dilakukan pada produk kerajinan bambu pembuatan stelan kursi meja, bangku malas (rosbang) dan balai besar. Sedangkan untuk pembuatan produk lainnya seperti tangga dan kerai tidak diperlukan pembuatan kerangka.

Tahapan produksi selanjutnya adalah finishing. Kerangka produk yang telah dihasilkan selanjutnya dirampungkan dengan memasang dipan duduk dan sandaran yang terbuat dari bambu yang dibelah dalam ukuran kecil (lebar $\pm 1 \mathrm{~cm}$ ), dipasang secara rapat dan diikat dengan benang. Oleh pengrajin dipan duduk dan sandaran tersebut disusun dengan dua jenis bentuk, yakni: 1) disusun secara lurus dan saling rapat antara satu dengan lainnya; dan 2) disusun secara silang sehingga membentuk motif kotak. Pengrajin menentukan motif lurus (saling rapat) pada dipan duduk, dan motif kotak pada dipan sandaran.

Setelah proses pemasangan dipan duduk dan dipan sandar, khusus untuk produk kerajinan tipe Betawi maka dilakukan proses pengikatan siku-siku bambu pada produk yang telah dihasilkan dengan menggunakan rotan. Rotan dibentuk seperti tali panjang dengan ukuran lebar \pm 2 milimeter. Proses akhir adalah pemberian cat pernis agar terlihat mengkilap dan melindungi produk dari jamur dan lumut. 
Yang membedakan secara mendasar pada produk kerajinan tipe biasa (original) dengan produk kerajinan yang telah dimodifikasi (tipe Betawi) adalah pada pemberian rotan sebagai ikatan pada tiap sikunya.

Pada produk kerajinan bambu tipe biasa (original) produk kerangka yang telah ada setelah dipasang dipan bangku dan duduk maka langsung menuju proses pemberian cat pernis. Sedangkan pada produk kerajinan tipe Betawi, produk terlebih dahulu diberikan/diikat rotan pada tiap sikunya baru kemudian diberikan cat pernis. Secara sederhana proses produksinya adalah sebagaimana disajikan oleh penulis pada gambar 2 berikut ini.

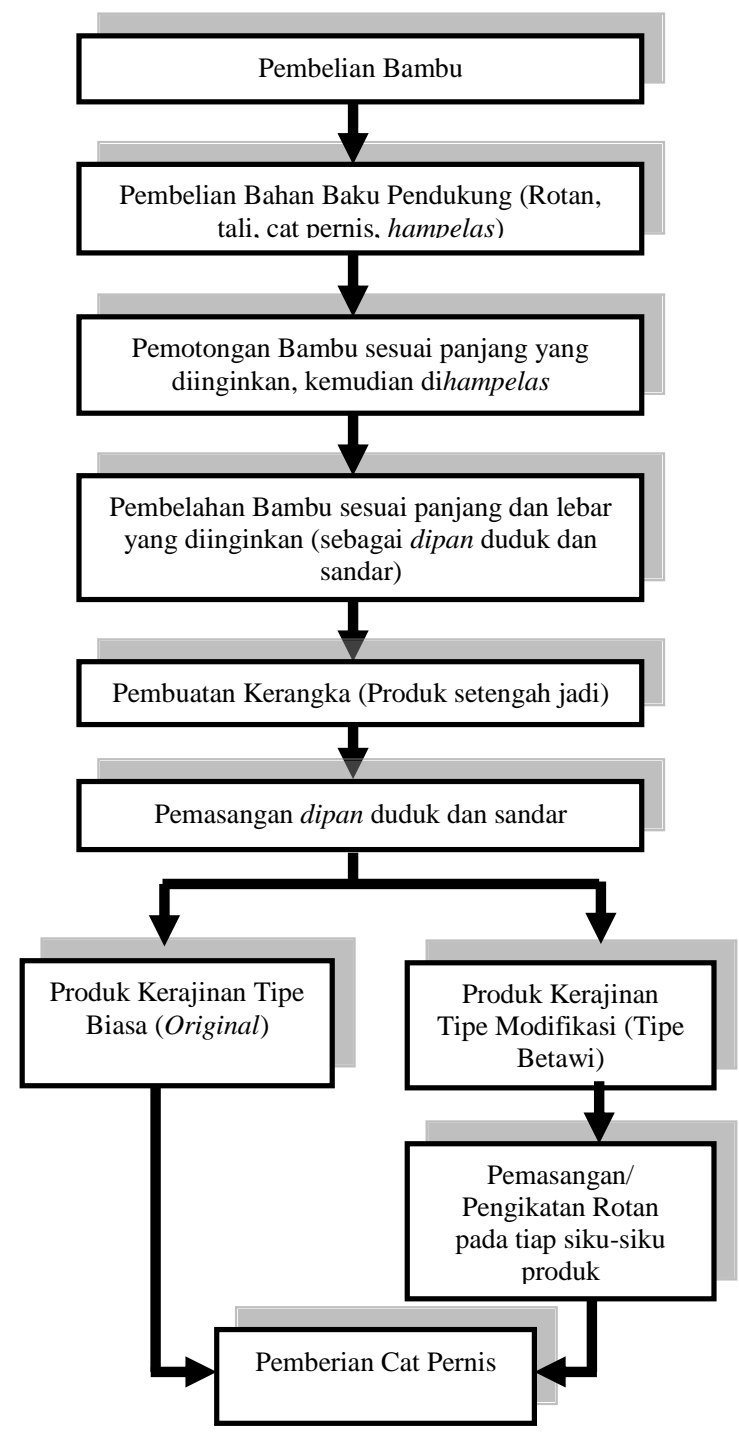

Gambar 2. Alur Proses Produksi

III.2. Perumusan Strategi

Teknik perumusan strategi yang digunakan oleh penulis adalah dengan menggunakan matriks yang terbagi dalam tiga tahapan (Nugraha:2007), yaitu sebagai berikut:

1. Tahap I : Tahap Masukan

2. Tahap II : Tahap Pencocokan 


\section{Tahap III: Tahap Keputusan}

Perumusan strategi dengan menggunakan matriks yang bersumber dari analisis kekuatan, kelemahan, peluang, dan ancaman (SWOT analysis) dalam usaha kerajinan bambu, sehingga dapat membantu penulis dalam mengidentifikasi, mengevaluasi, dan memilih strategi yang tepat dan sesuai untuk UKM pengrajin bambu di Kampung Pajeleran Kelurahan Sukahati.

1. Tahap Masukan

Tahap ini merupakan tahap pengumpulan informasi dasar yang dilakukan penulis, dengan alat analisis berupa Internal Factors Evaluation Matrix (IFE Matrix) dan External Factors Evaluation Matrix (EFE Matrix). Hasil identifikasi faktor-faktor internal dari usaha kerajinan bambu di kampung Pajeleran, dengan bobot dan peringkat yang diberikan penulis berdasarkan hasil observasi serta wawancara, adalah sebagaimana disajikan pada Tabel 3.

Tabel 3. Matriks IFE UKM Pengrajin Bambu Kampung Pajeleran Sukahati

\begin{tabular}{|c|c|c|c|}
\hline Key Internal Factors & Bobot & Rating & Skor \\
\hline \multicolumn{4}{|l|}{ Kekuatan (Strengths) } \\
\hline - $\quad$ Keunikan dan ke-khasan produk & 0,1 & 4 & 0,4 \\
\hline - Intuisi/naluri bisnis dari pengrajin & 0,15 & 4 & 0,6 \\
\hline - Semangat pantang menyerah dari pengrajin & 0,15 & 4 & 0,6 \\
\hline $\begin{array}{l}\text { Keterampilan pengrajin dalam menciptakan dan } \\
\text { mengembangkan desain produk }\end{array}$ & 0,15 & 4 & 0,6 \\
\hline - Hubungan antar pegawai dan pemilik & 0,05 & 2 & 0,1 \\
\hline \multicolumn{4}{|l|}{ Kelemahan (Weaknesses) } \\
\hline - $\quad$ Ketergantungan bahan baku & 0,1 & 1 & 0,1 \\
\hline - Pangsa pasar yang masih terbatas & 0,1 & 2 & 0,2 \\
\hline - Sifat dari bambu yang mudah dimakan rayap (bubuk) & 0,05 & 2 & 0,1 \\
\hline - Permodalan yang terbatas & 0,1 & 2 & 0,2 \\
\hline - $\quad$ Belum memiliki merek dagang & 0,05 & 2 & 0,1 \\
\hline Total & 1 & & 3 \\
\hline
\end{tabular}

Sumber: Observasi dan Wawancara 2010

Tabel 4. Matriks EFE UKM Pengrajin Bambu Kampung Pajeleran Sukahati

\begin{tabular}{lccc}
\hline \multicolumn{1}{c}{ Key External Factors } & Bobot & Rating & Skor \\
\hline Peluang (Opportunities) & & & \\
\hline $\begin{array}{l}\text { Terdapat pengusaha properti di Indonesia yang menyukai } \\
\text { furniture dari bamboo }\end{array}$ & 0,1 & 4 & 0,4 \\
- Desain yang unik dan klasik menciptakan peluang pasar & 0,15 & 4 & 0,6 \\
$\begin{array}{l}\text { yang belum teroptimalkan } \\
\text { Liputan/publikasi surat kabar lokal dapat menaikkan }\end{array}$ & 0,05 & 2 & 0,1 \\
$\begin{array}{l}\text { permintaan produk } \\
\text { Respon pasar dari luar daerah yang positif terhadap produk } \\
\text { kerajinan bambu tipe betawi }\end{array}$ & 0,1 & 3 & 0,3 \\
$\begin{array}{l}\text { Kebijakan Pemerintah Daerah yang mendukung keberadaan } \\
\text { UKM }\end{array}$ & 0,1 & 2 & 0,2 \\
\hline
\end{tabular}


Tabel 4 (Lanjutan). Matriks EFE UKM Pengrajin Bambu Kampung Pajeleran Sukahati

\begin{tabular}{lccr}
\hline Ancaman (Threats) & & & \\
\hline - Kontinuitas bahan baku bambu yang tidak dapat dipastikan & 0,15 & 3 & 0,45 \\
- Adanya kompetitor di bidang furniture dengan bahan baku & 0,15 & 3 & 0,45 \\
$\quad \begin{array}{l}\text { lebih awet (tahan rayap) } \\
\text { - Persaingan harga jual produk yang kurang sehat }\end{array}$ & 0,05 & 3 & 0,15 \\
- Harga bahan baku yang kurang stabil & 0,1 & 3 & 0,3 \\
- Kemampuan daya beli masyarakat yang relatif menurun & 0,05 & $\mathbf{2}$ & 0,1 \\
\hline
\end{tabular}

Sumber: Observasi dan Wawancara 2010

Total matriks IFE yang dimiliki UKM adalah sebesar 3,00. Hal ini menunjukkan bahwa posisi internal UKM pengrajin bambu Kampung Pajeleran Kelurahan Sukahati adalah kuat untuk keseluruhan posisi strategisnya dalam upaya memanfaatkan kekuatan dan mengantisipasi kelemahannya. Hasil identifikasi faktor-faktor eksernal dari usaha kerajinan bambu di kampung Pajeleran, dengan bobot dan peringkat yang diberikan penulis berdasarkan hasil observasi serta wawancara, adalah sebagaimana disajikan pada Tabel 4.

Total matriks EFE yang dimiliki oleh UKM adalah sebesar 3,05. Hal ini menunjukkan bahwa posisi eksternal UKM pengrajin bambu Kampung Pajeleran Kelurahan Sukahati adalah kuat untuk keseluruhan posisi strategisnya dalam upaya memanfaatkan peluang dan mengantisipasi ancamannya

2. Tahap Pencocokan

Tahap pencocokan (Matching Stage) merupakan pencarian strategi-strategi alternatif yang relevan bagi UKM. Pencarian alternatif strategi tersebut mengacu pada hasil penggabungan dari faktor internal dan eksternal UKM yang telah diteliti. Tahap ini juga merupakan tahap pencocokan yang fokus pada upaya menghasilkan strategi alternatif dan dapat dijalankan dengan memadukan faktor-faktor internal dan eksternal dalam sebuah matriks, sebagaimana disajikan dalam gambar berikut ini.

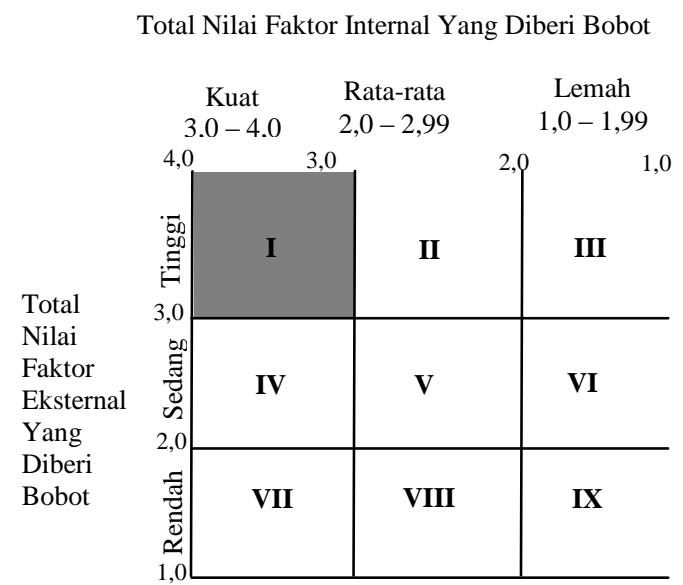

Gambar 3. Matriks Internal - Eksternal UKM Pengrajin Bambu Pajeleran

Berdasarkan hasil yang diperoleh dari tahap masukan, maka diketahui nilai total matriks IFE yang dimiliki oleh UKM adalah sebesar 3,00 dan nilai total matriks EFE yang 
dimiliki oleh UKM adalah sebesar 3,05. Sehingga dengan demikian pada tahap pencocokan ini UKM masuk dalam sel I yang berarti tumbuh dan membangun (Nugraha 2007).

3. Tahap Keputusan

Berdasarkan hasil analisis pada tahap masukan dan pencocokan, penulis menetapkan tiga alternatif strategi pengembangan usaha, yakni sebagai berikut:

a. Penetrasi Pasar

Strategi ini dilakukan dengan cara mengoptimalkan penjualan pada wilayah pemasaran produk yang telah ada. Hal ini dengan cara lebih intensif dalam melakukan "jemput bola" kepada calon konsumen, yakni dengan menawarkan produk secara langsung dan berkesinambungan.

Selain itu agar penetrasi dapat tercapai dengan optimal, maka perlu lebih diperhatikan penetapan harga jual produknya dengan melakukan compare pada produk furniture dari bahan baku lainnya.

b. Pengembangan/Perluasan Pasar

UKM pengrajin bambu juga perlu memperluas wilayah pemasarannya (market covarage) dengan beberapa cara seperti: 1) menjalin kerja sama dengan para pemilik kios penjual produk furniture di luar daerah; dan 2) menjalin kerja sama dengan Pemerintah Daerah Kabupaten Bogor dalam kegiatan pameran produk UKM.

c. Pengembangan Produk

UKM perlu senantiasa mengikuti selera pasar dalam hal desain produk, agar produk yang diciptakan dapat memikat hati para calon konsumen, baik konsumen baru maupun konsumen lama.

UKM perlu melakukan terobosan yang lebih kreatif lagi selain pengembangan produk dengan menggunakan rotan sebagai ikatan siku. Contohnya seperti mengkombinasikan kayu dengan bambu, atau mungkin dengan menambahkan busa atau bantal pada dudukan maupun sandaran kursi. Selain itu, para pengrajin juga dapat memanfaatkan keahlian yang dimilikinya dengan menawarkan jasa pembuatan berbagai produk kerajinan lainnya yang terbuat dari bambu, misalnya saung bambu.

Berdasarkan hasil kerja pada tahap 2 (Matching Stage) yang menggunakan matriks internal-external, selannjutnya pada tahap pengambilan keputusan (Decission Stage) penulis menggunakan matriks QSPM. Matriks ini dapat memberikan gambaran kelebihan-kelebihan relatif dari masing-masing strategi yang selanjutnya menjadi dasar ojektif dalam memilih salah satu strategi yang menjadi alternatif/pilihan. Matriks QSPM dari ketiga alternatif strategi pengembangan usaha kerajinan bambu di Kampung Pajeleran dapat dilihat pada Tabel 5.

Dari ketiga alternatif strategi yang telah dipilih, selanjutnya dapat diketahui bahwa Strategi Pengembangan Produk memiliki Total Attractive Score (TAS) yang paling tinggi, yakni sebesar 7,25. Dengan demikian strategi inilah yang dipilih dan paling direkomendasikan oleh penulis dalam upaya pengembangan usaha kerajinan bambu di wilayah Kampung Pajeleran Sukahati.

Pengembangan produk tidak hanya terbatas pada jenis furniture, namun pengrajin juga dapat memasuki jenis lainnya yang tergolong usaha kreatif. Contoh 
pengembangan produk adalah dengan mengkombinasikan pembuatan furniture bambu dengan pembuatan saung bambu yang unik, bersifat tradisional namun memiliki nilai seni yang relatif tinggi.

Tabel 5. Matriks QSPM

\begin{tabular}{|c|c|c|c|c|c|c|c|}
\hline \multirow[t]{2}{*}{ Critical Success Factors } & \multirow[t]{2}{*}{ Weight } & \multicolumn{2}{|c|}{$\begin{array}{l}\text { Penetrasi } \\
\text { Pasar }\end{array}$} & \multicolumn{2}{|c|}{$\begin{array}{l}\text { Pengembangan } \\
\text { Perluasan Pasar }\end{array}$} & \multicolumn{2}{|c|}{$\begin{array}{l}\text { Pengembangan } \\
\text { Produk }\end{array}$} \\
\hline & & (AS) & (TAS) & (AS) & (TAS) & (AS) & (TAS) \\
\hline \multicolumn{8}{|l|}{ Kekuatan (Strengths) } \\
\hline 1 Keunikan dan ke-khasan produk & 0,1 & 1 & 0,1 & 4 & 0,4 & 4 & 0,4 \\
\hline 2 Intuisi naluri bisnis dari pengrajin & 0,15 & 2 & 0,3 & 4 & 0,6 & 4 & 0,6 \\
\hline 3 Semangat pantang menyerah dari pengrajin & 0,15 & 2 & 0,3 & 4 & 0,6 & 4 & 0,6 \\
\hline $\begin{array}{l}4 \text { Keterampilan pengrajin dalam menciptakan dan mengembangkan } \\
\text { desain produk }\end{array}$ & 0,15 & 2 & 0,3 & 3 & 0,45 & 4 & 0,6 \\
\hline 5 Hubungan antar pegawai dan pemilik & 0,05 & 1 & 0,05 & 3 & 0,15 & 3 & 0,15 \\
\hline \multicolumn{8}{|l|}{ Kelemahan (Weaknesses) } \\
\hline 1 Ketergantungan bahan baku & 0,1 & 3 & 0,3 & 3 & 0,3 & 4 & 0,4 \\
\hline 2 Pangsa pasar yang masih terbatas & 0,1 & 2 & 0,2 & 4 & 0,4 & 4 & 0,4 \\
\hline 3 Sifat dari bambu yang mudah dimakan rayap (bubut) & 0,05 & 2 & 0,1 & 3 & 0,15 & 3 & 0,15 \\
\hline 4 Permodalan yang terbatas & 0,1 & 2 & 0,2 & 3 & 0,3 & 3 & 0,3 \\
\hline 5 Belum memiliki merek dagang & 0,05 & 2 & 0,1 & 3 & 0,15 & 3 & 0,15 \\
\hline \multicolumn{8}{|l|}{ Peluang (Opportunities) } \\
\hline $\begin{array}{l}1 \text { Terdapat pengusaha properti di Indonesia yang menyukai furniture } \\
\text { dari bambu }\end{array}$ & 0,1 & 2 & 0,2 & 4 & 0,4 & 4 & 0,4 \\
\hline $\begin{array}{l}2 \text { Desain yang unik dan klasik menciptakan peluang pasar yang belum } \\
\text { teroptimalkan }\end{array}$ & 0,15 & 2 & 0,3 & 4 & 0,6 & 4 & 0,6 \\
\hline 3 Liputan publikasi surat kabar lokal dapat menaikkan permintaan & 0,05 & 2 & 0,1 & 4 & 0,2 & 3 & 0,15 \\
\hline $\begin{array}{l}4 \text { Respon pasar dari luar daerah yang positif terhadap produk } \\
\text { kerajinan bambu tipe betawi }\end{array}$ & 0,1 & 2 & 0,2 & 3 & 0,3 & 3 & 0,3 \\
\hline 5 Kebijakan Pemerintah Daerah yang mendukung keberadaan UKM & 0,1 & 2 & 0,2 & 4 & 0,4 & 4 & 0,4 \\
\hline \multicolumn{8}{|l|}{ Ancaman (Threats) } \\
\hline 1 Kontinuitas bahan baku bambu yang tidak dapat dipastikan & 0,15 & 3 & 0,45 & 3 & 0,45 & 4 & 0,6 \\
\hline $\begin{array}{l}2 \text { Adanya kompetitor di bidang furniture dengan bahan baku lebih } \\
\text { awet (tahan rayap) }\end{array}$ & 0,15 & 2 & 0,3 & 2 & 0,3 & 3 & 0,45 \\
\hline 3 Persaingan harga jual produk yang kurang sehat & 0,05 & 2 & 0,1 & 2 & 0,1 & 3 & 0,15 \\
\hline 4 Harga bahan baku yang kurang stabil & 0,1 & 2 & 0,2 & 3 & 0,3 & 3 & 0,3 \\
\hline 5 Kemampuan daya beli masyarakat yang relatif menurun & 0,05 & 3 & 0,15 & 3 & 0,15 & 3 & 0,15 \\
\hline Total & & & 4,15 & & 6,7 & & 7,25 \\
\hline
\end{tabular}

\section{Kesimpulan}

Berdasarkan pada hasil analisis dan pembahasan yang telah dipaparkan, maka penulis dapat memberikan kesimpulannya sebagai berikut:

1. Keberadaan UKM kerajinan bambu di kampung Pajeleran kelurahan Sukahati telah berlangsung secara turun temurun dari generasi ke generasi, diperkirakan telah ada sejak tahun 1960-an. Produk furniture bambu yang dihasilkan oleh para pengrajin cukup bervariasi, namun beberapa jenis kerajinan yang rutin atau secara teratur dibuat oleh pengrajin adalah seperti: 1). Kursi; 2). Meja; 3). Kerai dan 4). Tangga.

2. Berdasarkan hasil yang diperoleh dari tahap masukan, maka diketahui nilai total matriks IFE yang dimiliki oleh UKM adalah sebesar 3,00 dan nilai total matriks EFE yang dimiliki oleh UKM adalah sebesar 3,05. Sehingga dengan demikian pada tahap pencocokan ini UKM masuk dalam sel I yang berarti tumbuh dan membangun.

3. Terdapat tiga alternatif strategi yang dapat diterapkan dalam upaya mengembangkan usaha kerajinan bambu di wilayah Kampung Pajeleran Kelurahan Sukahati adalah sebagai berikut: 1). Penetrasi pasar; 2). Pengembangan/ perluasan pasar; dan 3). Pengembangan produk. 
4. Matriks QSPM menetapkan strategi pengembangan produk sebagai strategi yang paling direkomendasikan, dikarenakan memiliki skor TAS tertinggi di antara dua alternatif strategi lainnya.

\section{Daftar Pustaka}

Anonim. 1995. Undang-undang Nomor 9 Tahun 1995 tentang Usaha Kecil. Bogor. 2009. Laporan Tahunan Kelurahan Sukahati Kecamatan Cibinong Kabupaten

Andika. 2007. Strategi Pengembangan Usaha Mikro Kecil dan Menengah. Program Studi Administrasi Bisnis, Universitas Padjadjaran, Bandung.

Anuraga, Pandji dan H. Djoko Sudantoko. 2002. Koperasi, Kewirausahaan, dan Usaha Kecil, Rineka Cipta, Jakarta.

David, R. Fred. 2003. Strategic Management Concept \& Cases, ninth edition, Prentice Hall, New Jersey.

Nugraha, Muhammad Qudrat. 2007. Universitas Terbuka, Jakarta.

Saladin, Djaslim. 2004. Manajemen Strategi \& Kebijakan Perusahaan. Linda Karya, Bandung.

Sugiyono. 2002. Metode Penelitian Bisnis. Alfabeta, Bandung.

Umar, Husein. 2001. Strategic Management in Action (Konsep, Teori, dan Teknik Menganalisis Manajemen Strategis Strategic Business Unit Berdasarkan Konsep Michael R. Porter, Fred R. David, dan Wheelen-Hunger. Gramedia Pustaka Utama. Jakarta.

. 2003. Studi Kelayakan Bisnis (Edisi 2). Gramedia Pustaka Utama, Jakarta.

Wheelen, Thomas L. dan Hunger, J. David. 2001. Strategic Management. AdsisonWesley Publishing Company, Inc. USA.

Wijaya E.A., N. W. Utami dan Saefudin, 2004. Panduan Membudidayakan Bambu. Puslitbang Biologi LIPI, Bogor.

http://id.wikipedia.org/wiki/bambu. Diakses pada tanggal 18 Desember 2009 